\title{
A refinement of the Kittaneh-Manasrah inequality
}

\section{Nicuşor Minculete}

\section{ABSTRACT.}

The purpose of this paper is to give refinement for the Kittaneh-Manasrah inequality which improves the inequality of Young. We also give several applications.

"DiMitrie CANTEMIR" UNIVERSITY

BISERICII ROMÂNE 107

500026 BRAŞOV, ROMÂNIA

E-mail address: minculeten@yahoo.com

Received: 21.03.2011; In revised form: 13.09.2011; Accepted: 15.09.2011.

2010 Mathematics Subject Classification. 26D15.

Key words and phrases. Kittaneh-Manasrah's inequality, Young's inequality, arithmetic functions. 